San Jose State University

SJSU ScholarWorks

Faculty Publications

Health Science and Recreation

October 2013

\title{
Preparing public librarians for consumer health information service: A nation-wide study
}

L. Luo

San Jose State University, lili.luo@sjsu.edu

Van M. Ta Park

San Jose State University, van.ta@sjsu.edu

Follow this and additional works at: https://scholarworks.sjsu.edu/healthsci_rec_pub

Part of the Library and Information Science Commons, and the Medicine and Health Sciences

Commons

\section{Recommended Citation}

L. Luo and Van M. Ta Park. "Preparing public librarians for consumer health information service: A nationwide study" Library and Information Science Research (2013): 310-317.

This Article is brought to you for free and open access by the Health Science and Recreation at SJSU

ScholarWorks. It has been accepted for inclusion in Faculty Publications by an authorized administrator of SJSU

ScholarWorks. For more information, please contact scholarworks@sjsu.edu. 


\title{
Preparing Public Librarians for Consumer Health Information Service: A Nationwide Study
}

\author{
Lili Luo \& Van Ta Park
}

\begin{abstract}
A nationwide survey study was conducted to understand how to prepare public librarians for consumer health information service. Findings indicate that the popular health information needs encountered by public librarians cover a wide variety of topics including the human body, a medical/health condition, a disease, a medical concept, and fitness/diet/nutrition. The top two challenges faced by public librarians when providing consumer health information service are difficulty in interpreting patrons' questions and lack of knowledge about available and trusted/appropriate medical/health information sources. Public librarians wish to receive training on a number of topics that could help address the challenges they face, and the most favorable training format for them, among all the options provided in the survey, is self-paced online tutorial. This study constitutes the basis to establish training requirements and develop training programs to meet the needs of public librarians. Their mastery of the necessary skills, knowledge and competencies via training will lead to the effective and efficient delivery of consumer health information service in public libraries, and ultimately generate optimal patron experience.
\end{abstract}

\section{Introduction}

Health literacy is defined as "the degree to which individuals have the capacity to obtain, process and understand basic health information and services needed to make appropriate health decisions" (Nielsen-BohIman, Panzer, Kindig, 2004, n.p.). Health literacy is a foundational and essential notion that connects a variety of key issues in health policy, health services research, health communication, and health care delivery (Norman \& Skinner, 2006; Bass, 2005; McCray, 2005; Erlen, 2004; Parker, Ratzan, \& Lurie, 2003; Rudd, Moeykens, \& Colton, 1999; Zarcadoolas, Pleasant, \& Greer, 2005). However, according to the Institute of Medicine (Nielsen-Bohlman, et al., 2004), nearly half of all American adults, about 90 million people, have difficulty understanding and using health information, and the nation's poor health literacy has been characterized as public health's "silent epidemic" (Marcus, 2006).

The profound consequences of poor health literacy have been extensively documented, revealing that a significant array of health outcomes are often negatively impacted, including inappropriate use of services, risk of hospitalization, health screening, knowledge of one's disease, and ability to manage chronic illnesses like hypertension and diabetes (NielsenBohlman, et al., 2004; Whelan, 2009; CSAAMA, 1999; Berkman et al., 2004; Orban, 2005). Recently there has been a growing recognition of the crucial need to enhance health literacy among the public (Siegel,2007; Orban, 2005). Former U.S. Surgeon General Carmona (2006) noted that improving the nation's health literacy should be a national health and public policy priority. Meanwhile, health literacy has been identified as a priority by organizations like the 
Institute of Medicine (IOM, 2003), the National Library of Medicine (NLM, 2004), and the US Department of Health and Human Services' Healthy People 2020 (HHS, 2010).

An important pathway to health literacy enhancement is efficient and effective access to highquality and comprehensible health information, and public libraries are uniquely positioned to play a supporting role in this regard (Lyon, 2001; Baker \& Manbeck, 2002). They provide a nocost, convenient way to assist the public in navigating health information resources, fulfilling their health information needs, and ultimately improving their health literacy (Zionts, Apter, Kuchta, and Greenhouse, 2010). The public library is often the first place many people consult when seeking information on important health topics, such as health care coverage eligibility, disease prevention and treatment. (Zionts, et al., 2010; Westermann-Cicio, 2003). In focus groups conducted by the Reference Point Foundation, all groups reported using libraries for general health information needs, and $60 \%$ of the participants conveyed that libraries were among their preferred sources of health information (Derring \& Harris, 1996). Among the various kinds of inquiries of the public, health is perceived to be a top-ten topic area (Wood, Lyon, Schelle, Kitendaugh, Cid \& Siegel, 2000).

Public libraries play three important roles in patrons' quest for health information. First, public libraries provide print and electronic resources on consumer health, and a small percentage even have specialized consumer health centers that patrons can use to meet their information needs (Chobot, 2002); secondly, the free computer and Internet service offered by public libraries allow patrons easy access to the vast amount of online health information, which is much needed by those representing vulnerable populations, such as those disadvantaged in terms of income, education, age or ethnicity (Malachowski, 2011); thirdly, humanintermediated reference services provided by public librarians can help patrons achieve their objectives of health information seeking more successfully. This study focuses on the third role, aiming to understand how to effectively prepare public librarians for consumer health information service.

\section{Problem Statement}

Public librarians are a source frequently consulted by patrons with health information needs (Parker \& Kreps, 2005). Health information inquiries account for as many as $60 \%$ of the total reference inquiries at public libraries (Wood et al., 2000). Yet many public librarians are not comfortable, confident or competent in providing reference service to health information seekers due to concerns such as an inadequate understanding of health literacy, provision of misinformation and possible intrusion on patron privacy (Wood et al., 2000; Parker \& Kreps, 2005; Borman \& McKenzie, 2005). As a result, the level of service delivered by public librarians has shown substantial variability (Wood et al., 2000). Since patrons may rely on the health information they obtain from libraries to make important decisions regarding their personal well-being, it is suggested that librarians are mindful of the far-reaching implications of their service and are adequately prepared (Orban, 2005).

In order to help public librarians best execute their function of intermediary in reference transactions involving health information needs, professional training is indispensable (Baker \& Manbeck, 2002; Harris, et al., 2005; Parker \& Kreps, 2005). Furthermore, consumer health information services will be most successful when the information is provided at the time of 
need and at the point of service, and this demands a level of librarian readiness that can only be achieved from sufficient training. Empirical research is needed to identify training needs and establish training requirements. This nation-wide study aims to present a comprehensive analysis of the training needs for public librarians, which will constitute the basis for training/education program design, lead to improved preparedness of public librarians in fulfilling patrons' health information needs, and ultimately contribute to the nation's health literacy enhancement.

The study seeks to answer the following three research questions:

- What are the types of health information needs fulfilled by reference services at public libraries?

- What are the challenges encountered by public librarians when assisting patrons with health information needs?

- What are public librarians' desired content and delivery options of training on providing consumer health information service?

\section{Literature Review}

Addressing health literacy by enabling patients to understand and act in their own interest is a critical pathway to improved quality of care in the nation (Nielsen-Bohlman et al., 2004). Patients and consumers are taking more responsibility for their own health care as the health care system increasingly involves patients and families in treatment decisions (Kouame et al., 2005). With the passage of the Patient Protection and Affordable Care Act (PPACA), there is an increased emphasis on the public's active, rather than passive, participation in issues concerning their health status. This trend is referred to as "patient activation" (Malachowski, 2011).

Poor health literacy has been identified as a roadblock to patient activation, especially at a time when the health system is increasingly fragmented, complex, specialized and technologically sophisticated (Parker, 2000). People with low functional health literacy have more difficulty navigating the health care system and obtaining services. They are less likely to comprehend the written and oral information given to them by providers, and more likely to suffer higher health care costs (Kripalani \& Weiss, 2006). They disproportionately have poorer health outcomes than those with high levels of health literacy. Older people, non-Whites, immigrants, and low-income people constitute a large segment of the population with low health literacy (Kripalani \& Weiss, 2006). Particularly, the over-65 population will constitute a full $20 \%$ of the total U.S. population by 2030. Six out of ten Baby Boomers will be managing multiple chronic illnesses and will need access to timely, reliable and accurate healthcare information in order to make timely and accurate healthcare decisions (AHA, 2007).

On the other hand, accessing and evaluating quality health information can be challenging in the Internet age. About $70 \%$ of the studies on health information Websites found quality to be a problem due to incompleteness and inaccuracy (Eysenbach, Powell \& Kuss, 2002). This problem is further compounded by people's lack of understanding of information retrieval and evaluation strategies. A study of health information seeking behavior revealed that no study 
participants checked the "About Us" section, disclaimers, or disclosure statements when viewing information gathered from the Web (Eysenbach \& Köhler, 2002). In another study about the public's use of Internet health resources, three-quarters of health seekers checked the source and date "only sometimes," "hardly ever," or "never," which translated to about 85 million Americans gathering health advice online without consistently examining the quality indicators of the information they find (Fox, 2006).

Zionts et al. (2010) reported that $75 \%$ of the participants in a consumer health literacy study expressed desire for help in learning how to access the Internet and wished for better-quality information. As the first point of access for many people in their information seeking process, public libraries are well placed to offer the help. Chobot (2002) conducted a literature review on how public libraries disseminate health information to the public, and two of her key findings were "consumers report that health information found through libraries is valuable and affects their health care decisions" and "public libraries are important providers of health information" (p. 7).

The number of health-related questions asked by public library patrons has steadily increased in the past three decades and escalated exponentially since late 1990s, with the most dramatic growth in questions about specific diseases, medical treatment, drugs and health care systems (Marshall, Sewards \& Dilworth, 1991; Baker, Sprang \& Gogolowski, 1998; Chobot, 2002). However, public librarians are not necessarily well prepared for providing consumer health information service. A number of studies reveal that they face various kinds of challenges when helping patrons with health information needs.

In their survey of 48 public librarians in Ontario, Canada, Marshall et al. (1991) discovered three common problems in the provision of consumer health information service: 1) inability or unwillingness of patron to present the question clearly enough for the librarian to understand what the patron wanted to know; 2) relevant resources were missing or unavailable; and 3) library did not own material that might be useful. They recommend that workshops and other forms of continuing education for public librarians be organized.

Sprang and Baker (2000) identified four major concerns: ethical obligations to provide access to published medical information while not providing medical advice; the best way to conduct reference interviews while walking this ethical tightrope; the selection of materials for consumer health reference collections; and providing equal access for all patrons seeking health information, particularly patrons in rural areas. They concluded that public librarians need additional resources and training to meet the growing health information needs of library patrons.

In a survey study about the training needs of public librarians in western Pennsylvania, Wessel, Wozar and Epstein (2003) discovered that librarians were unsure about what a basic health collection should contain and what reference books should be used to answer specific disease questions. Using the Internet to answer health-related questions was also a challenge and librarians had concerns about the quality of the retrieved information. Other challenges included difficulty with medical terminology, feeling pressed to assist individuals in interpreting and understanding information without giving the impression of offering medical advice, being uncomfortable in dealing with individuals under stress from coping with a difficult diagnosis or 
having to make a crucial health decision, and having limited time available to answer medical questions.

Linna, Wildemuth, Gollop, Hull, Silbajoris and Monning (2004) surveyed 83 librarians in North Carolina and found that librarians rated their knowledge in accessing health information as 3.4 on a 5 -piont scale ( 1 =very little and $5=$ a great deal). They would like additional training on health information/resources, meeting patrons' needs with particular resources, and ethical issues.

Kouame et al. (2005) discussed issues surrounding the provision of health information service in public libraries, and identified several challenging areas where more efforts are needed in improving librarian preparedness:

- It is important to determine the health information needs of a public library's user community, and promote and provide services that target the community's specific needs.

- There is a sense of intimidation by medical librarians among public librarians, which makes them hesitant to contact medical librarians for assistance about consumer health questions.

- Patrons tend to blur the line between health information and health advice and they do not understand that librarians' role is limited to helping them with health information needs and not offering health advice.

- There are several practical and psychological pressures that librarians face in providing health information to patrons, such as difficulty in handling sensitive, emotional questions, gaining the patron's trust and acceptance in order to probe for further details to answer their question.

- Patrons' health inquiries are often incomplete and unclear; and they anticipate that public libraries have tailored resources for every special health topic and all health information needs can be addressed.

To overcome the above challenges, Kouame et al. (2005) suggested that public librarians receive proper training in providing consumer health information service. As indicated previously, this suggestion is echoed throughout the literature. Particularly, in Harris et al.'s (2005) study to examine public librarians' performance during a major public health crisis, they found that many librarians did not respond to patrons' health information needs well. They stated that, "given the potentially serious consequences of poor information service in response to consumer health inquiries, the findings in this study raise serious questions about the preparedness of library staff to respond to health-related inquiries, especially in urgent situations" (p. 151).

The above publications have provided strong testaments to the need for consumer health information service training for public librarians; however, a thorough literature search only yielded three documented training efforts. Wessel et al. (2003) described a series of training workshops provided by an academic medical center library to public librarians in western Pennsylvania. The workshops led to librarians' increased comfort level with health-related 
reference questions, and increased use of MedlinePlus and other quality information resources. Turner-McGrievy and Campbell (2009) shared results of the evaluation of an online course on saturated fat for public librarians, and concluded that an online course can be an effective way to increase self-efficacy about helping patrons with nutrition-related questions. Zionts et al. (2010) discussed a locally established fellowship in Pittsburg that enabled a public library to partner with health care experts and the Medical Library Association (MLA) to provide training for public librarians. The fellowship received positive participant ratings regarding improved familiarity and preparedness with consumer health information in multiple dimensions.

The literature review has indicated that public librarians face challenges when providing consumer health information service and there is a substantial need for effective and efficient training. However, the empirical research that sought to identify the challenges was all locally focused and dated - the most recent study (Linna et al., 2004) was conducted a decade ago. The training programs discussed in the literature were also locally organized, catering to the needs of public librarians in one single library or one particular region. Given the prevailing budget and time constraints among public libraries in the nation, the chances are slim for the efforts to be replicated. Therefore, a nation-wide study is much needed to examine consumer health information service provided by public librarians, identify the barriers and challenges they face, and determine the training requirements.

\section{Methodology}

The study population consisted of public librarians that provide human-intermediated information service to patrons via reference services or other library programs. The probability sampling method, systematic random sampling, was used to select the study sample. The online directory of public libraries on www.publiclibraries.com was used as the sampling frame. Publiclibraries.com is recognized by many public libraries as an advocate for the use and support of local public libraries in every city across the United States, and contains a complete directory of public libraries in the country, organized by state/city. Under each state, every fifth hyperlinked library in the directory was selected and evaluated for its eligibility for inclusion in the sample. A total number of 1,547 libraries were selected and included in the study sample, while 127 were excluded from the study because of one of following criteria:

- The hyperlink of the library did not work and led to a page not found.

- The library's Webpage did not contain any electronic contact information.

- The library's contact information was inaccurate.

- Login was required to submit an information request on the library's Webpage.

- When all libraries in a library system shared the same electronic contact information and more than one library in the system was selected, only the first one would be included in the study.

For each selected library, the library Website was carefully examined for electronic contact information such as an email address or a Web form to submit an information request. If the library director's email address was available, a message was emailed to the library director, explaining the study and inviting participation from librarians, particularly reference librarians 
that directly help patrons with their health-related questions. If not, the message would be sent via the Web form or the email address the library uses to collect email reference questions.

An online survey was used as the data collection instrument. The survey questions were constructed to measure the following variables: 1) frequency and venues of public librarians' encounters with health-related questions from patrons; 2 ) topics of patrons' questions; 3 ) challenges librarians face when answering patrons' questions; 4) experience of training on consumer health information service; 5 ) awareness of training opportunities; 6 ) desired format of training; 7) desired content of training; and 8) librarians' work setting.

Variable 1 and 2 reflect upon the first research question "what are the types of health information needs fulfilled by reference services at public libraries"; variable 3 focuses on the second research question "what are the challenges encountered by public librarians when assisting patrons with health information needs"; variable 4 to 7 cover the third research question "what are public librarians' desired content and delivery options of training on providing consumer health information service"; and, variable 8 seeks to provide a description of survey respondents' work environment.

The online survey was made available for three weeks, and by the time of the survey closure, a total number of 460 responses were received. Assuming on average each library has one fulltime reference librarian, the survey response rate would be $29.7 \%$. In Nutly's (2008) study about the adequacy of survey response rates, he concluded that online survey response rates varied from $20 \%$ to $47 \%$, with an average of $33.3 \%$. Compared to that, the response rate in this study falls within the reasonable range.

\section{Results}

5.1. Descriptive Analysis

Respondents were first inquired about how frequently they helped patrons with their health information needs, and most of them (41.1\%) reported "a few times a month", as shown in Figure 1.

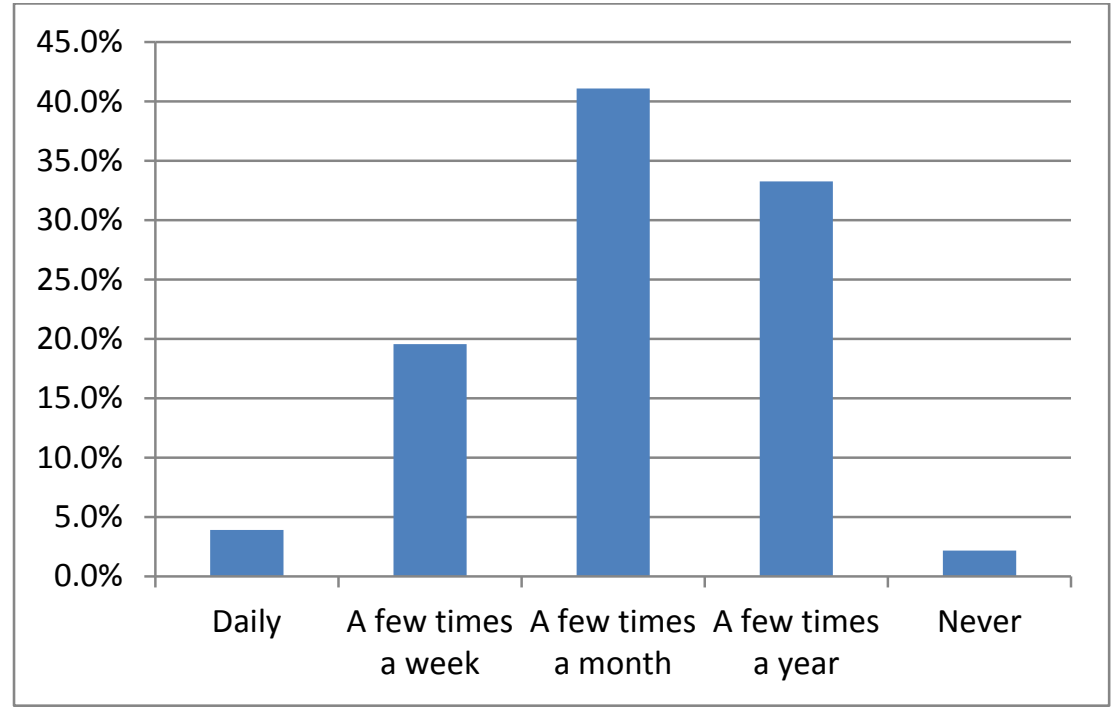

Figure 1. Frequency of helping patrons with health information needs 
Regarding where librarians received health-related questions, the reference desk and telephone reference service were the two predominant venues, as shown in Table 1.

\begin{tabular}{|l|r|}
\hline Venue & $\begin{array}{r}\text { Selected by \% of } \\
\text { respondents }\end{array}$ \\
\hline Reference desk & $93.8 \%$ \\
\hline Telephone reference service & $40.7 \%$ \\
\hline Email reference service & $8.8 \%$ \\
\hline In the stacks when librarians are shelving or roving & $4.4 \%$ \\
\hline Online real-time chat reference service & $4.2 \%$ \\
\hline $\begin{array}{l}\text { Service points beyond the reference desk, such as the } \\
\text { circulation desk, snail mail, and reference appointment }\end{array}$ & $3.3 \%$ \\
\hline Library literacy program & $2.0 \%$ \\
\hline At public access computers & $1.8 \%$ \\
\hline Texting-based reference service & $1.1 \%$ \\
\hline $\begin{array}{l}\text { Other library programs, particularly health information } \\
\text { outreach programs }\end{array}$ & $0.9 \%$ \\
\hline
\end{tabular}

Table 1. Venues of receiving health-related questions

The topic of patrons' questions is an indicator of the type of health information needs they have and Table 2 presents a break-down of these topics, rank ordered by the percentage of respondents that selected each topic. The small percentage of miscellaneous questions include those that could not be grouped into any of the other topical categories, such as questions on how to locate books on a certain health-related topic, how parents can help children address a specific disease (e.g. ADHD), careers in health, medical history such as first aid in World War I, and the impact of environmental factors on health (mold, magnetism, pollution, etc.).

\begin{tabular}{|l|c|}
\hline \multicolumn{1}{|l|}{$\begin{array}{l}\text { Topic of patrons' questions } \\
\text { Questions seeking factual information about the human body, a } \\
\text { medical/health condition, a disease, or a medical concept }\end{array}$} & $\begin{array}{r}\text { Selected by \% of } \\
\text { respondents }\end{array}$ \\
\hline Questions about fitness, and dietary and nutritional information & $86.5 \%$ \\
\hline $\begin{array}{l}\text { Questions about the treatment options/healing process of a } \\
\text { medical/health condition or a disease, including complementary } \\
\text { and alternative therapies }\end{array}$ & $77.7 \%$ \\
\hline $\begin{array}{l}\text { Questions about the symptoms of a medical/health condition or a } \\
\text { disease }\end{array}$ & $73.2 \%$ \\
\hline $\begin{array}{l}\text { Questions about the cause and effect of a medical/health } \\
\text { condition or a disease }\end{array}$ & $66.6 \%$ \\
\hline $\begin{array}{l}\text { Questions about different aspects of an over-the-counter or } \\
\text { prescription medication }\end{array}$ & $50.9 \%$ \\
\hline
\end{tabular}




\begin{tabular}{|l|r|}
\hline $\begin{array}{l}\text { Questions about medical/health services, organizations, } \\
\text { regulations, and statistics }\end{array}$ & $38.9 \%$ \\
\hline $\begin{array}{l}\text { Questions about the prevention of a medical/health condition or } \\
\text { a disease }\end{array}$ & $30.5 \%$ \\
\hline Questions about sex or sex-related diseases/conditions & $14.2 \%$ \\
\hline Miscellaneous questions & $1.1 \%$ \\
\hline
\end{tabular}

Table 2. Topics of health-related questions

On the subject of challenges librarians face when answering health-related questions, the survey responses were grouped into the following categories:

- Difficulty in interpreting patrons' questions (61.8\%), usually due to patrons not being able to articulate their information need, lacking knowledge of the topic they inquire about, providing incorrect spelling or pronunciation of the medical terms in their questions, being reluctant to discuss the specifics of their medical conditions/diseases, and oversharing unnecessary details.

- Lack of knowledge about available medical/health information sources (34.2\%).

- Difficulty in formulating effective search strategies (21.9\%).

- Difficulty in handling the emotional aspect of health-related questions (21.6\%).

- Limited availability of useful medical/health information sources (8.3\%). Respondents explained the limitation as follows: 1) many library patrons prefer print resources, but the library lacks up-to-date print collections on medical/health topics; 2) much of the medical/health information is written at a professional level, too technical for patrons' reading comprehension; 3 ) the library lacks information on specific topics that patrons inquire about, such as a particular disease or drug; 4) it is difficult to locate reliable information on emerging treatments and medications.

- Difficulty in communicating the role of librarians to patrons (7.1\%) - librarians are not medical/health professionals and, therefore, are not qualified to offer advice; their role is to assist patrons in locating the information they need.

More than half of the respondents $(55.0 \%)$ had not received any training on helping patrons with health information needs, and were also not aware of any training opportunities. Among those who had received training, their training came from the following sources: 1) training sessions provided by national organizations and their regional branches, such as the National Network of Libraries of Medicine (NNLM), National Institute of Health (NIH), National Library of Medicine (NLM), and American Library Association (ALA); 2) training sessions provided by the State Library or other state-level training agencies such as Infopeople in California; 3 ) training sessions provided by local medical/health libraries or organizations; 3) classes about medical/health resources taken at graduate school; 4) journal articles and books; 5) workshops at library conferences; 6 ) training sessions by vendors of medical/health databases. The format of training included both online Webinars and face-to-face sessions. Content-wise, the focus was invariably on information resources, particularly MedlinePlus, PubMed, and local health reference material. 
When asked about the training format that best fit their needs, the majority of respondents (51.1\%) chose "self-paced online tutorials", as shown in Figure 2.

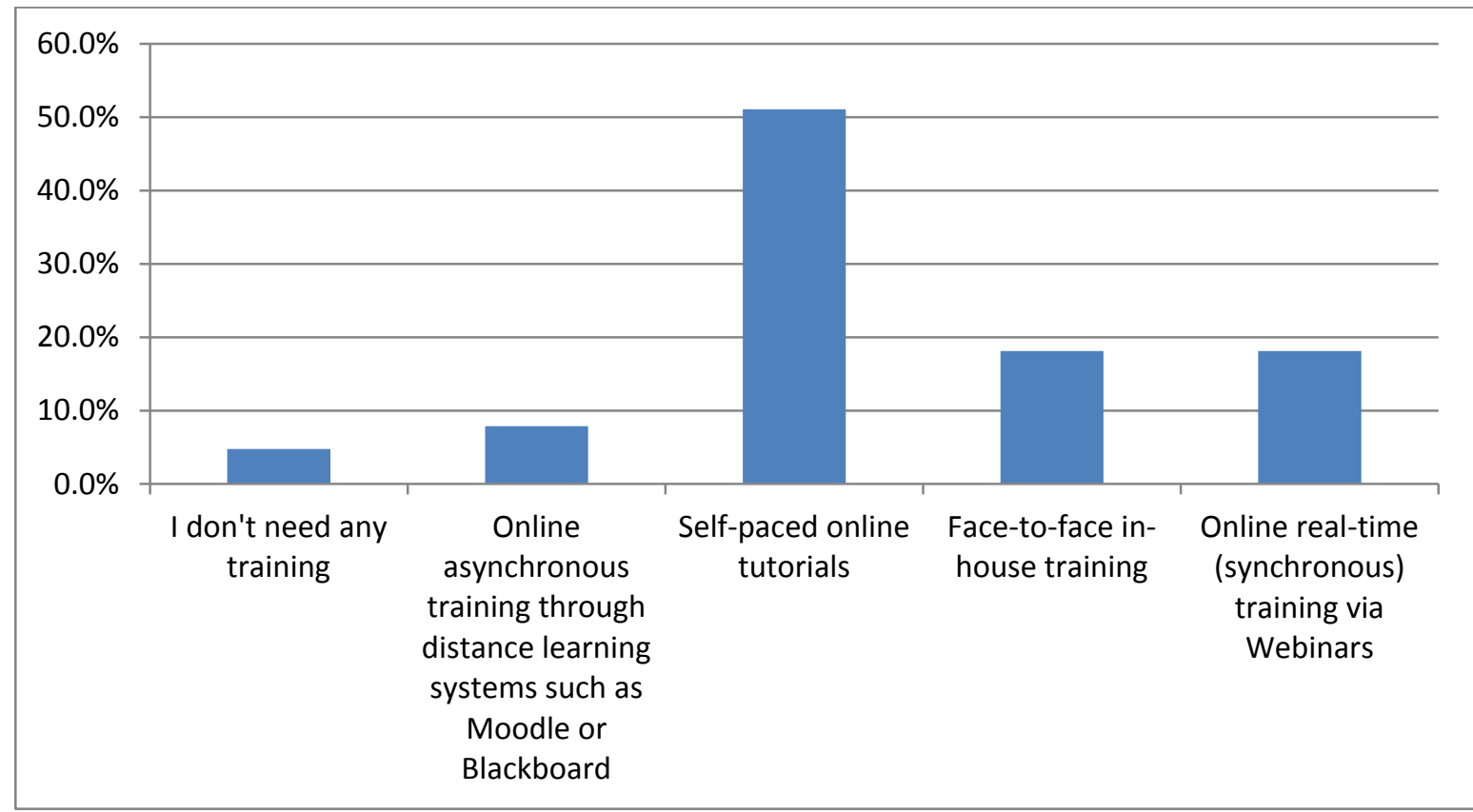

Figure 2. Desired training format

Among the desired topics of training, "knowledge/navigation of up-to-date health information resources" was most popular, selected by almost four-fifth of the respondents.

\begin{tabular}{|l|r|}
\hline Topic of training & $\begin{array}{r}\text { Selected by \% of } \\
\text { respondents }\end{array}$ \\
\hline $\begin{array}{l}\text { Knowledge/Navigation of up-to-date health information resources, } \\
\text { including but not limited to core online health resources, mobile health } \\
\text { resources, popular magazines, multimedia resources, and print } \\
\text { publications of health/medical organizations like NIH }\end{array}$ & $76.7 \%$ \\
\hline Health reference interview & $64.3 \%$ \\
\hline $\begin{array}{l}\text { Serving health information needs of special populations, such as } \\
\text { seniors, teens, ethnic groups, people with low literacy level, non- } \\
\begin{array}{l}\text { English speaking populations, military and veterans, and Lesbian, Gay, } \\
\text { Bisexual, and Transgender (LGBT) }\end{array}\end{array}$ \\
\hline Legal and ethical considerations & $55.8 \%$ \\
\hline $\begin{array}{l}\text { Evaluating health information using various criteria, such as credibility, } \\
\text { authority, currency, and readability }\end{array}$ & $53.4 \%$ \\
\hline Partnering with community or other health organizations & $51.2 \%$ \\
\hline $\begin{array}{l}\text { Marketing library programs and services about consumer health } \\
\text { information }\end{array}$ & $45.4 \%$ \\
\hline $\begin{array}{l}\text { Developing and delivering health-related library programs and } \\
\text { collections }\end{array}$ & $44.7 \%$ \\
\hline
\end{tabular}




\begin{tabular}{|l|r|}
\hline Community needs assessment for health information needs & $34.0 \%$ \\
\hline Creating healthy library work environments & $24.0 \%$ \\
\hline
\end{tabular}

Table 3. Desired topics of training

Regarding the respondents' library settings, 39.9\% worked in suburban areas, $29.1 \%$ worked in rural areas, $28.4 \%$ worked in urban areas, and the remaining $2.5 \%$ worked in libraries that were located in between urban, suburban and rural areas.

5.2. Inferential Analysis

To further understand the relationships between some of the variables and their statistical significance, Chi-square tests were conducted to test the following null hypotheses:

1. The number of challenges librarians face when answering health-related questions is unrelated to how frequently they help patrons with health information needs.

2. The number of challenges librarians face when answering health-related questions is unrelated to the number of desired topics in a consumer health information service training curriculum.

3. The number of challenges librarians face when answering health-related questions is unrelated to whether they have received any training on serving patrons with health information needs.

4. The frequency with which librarians help patrons with health information needs is unrelated to their library setting.

5. The frequency with which librarians help patrons with health information needs is unrelated to the content variety of health-related questions they receive.

6. The frequency with which librarians help patrons with health information needs is unrelated to the number of desired topics in a consumer health information service training curriculum.

7. Whether librarians have received any training on serving patrons with health information needs is unrelated to their work setting.

A total of five of the null hypotheses were rejected, and the results of the Chi-square tests are presented in Table 4. The number in the far left column corresponds with the null hypothesis number from the above list.

\begin{tabular}{|l|l|l|r|r|r|}
\hline$\#$ & Variable (attributes) & Variable (attributes) & $\begin{array}{r}\text { Chi- } \\
\text { square } \\
\text { value }\end{array}$ & $\begin{array}{r}\text { Degree } \\
\text { of } \\
\text { freedom }\end{array}$ & $\begin{array}{r}p \\
\text { value }\end{array}$ \\
\hline 1 & $\begin{array}{l}\text { The frequency with which } \\
\text { librarians help patrons with } \\
\text { health information needs (never, } \\
\text { a few times a year, a few times a } \\
\text { month, a few times a week, daily) }\end{array}$ & $\begin{array}{l}\text { The number of challenges } \\
\text { librarians face when answering } \\
\text { health-related questions (none, } \\
1 \text { to 2, 3 to 5) }\end{array}$ & 78.847 & 8 & .000 \\
\hline 3 & $\begin{array}{l}\text { Whether librarians have received } \\
\text { any training on serving patrons }\end{array}$ & $\begin{array}{l}\text { The number of challenges } \\
\text { librarians face when answering }\end{array}$ & 9.841 & 2 & .007 \\
\hline
\end{tabular}




\begin{tabular}{|c|c|c|c|c|c|}
\hline & $\begin{array}{l}\text { with health information needs } \\
\text { (yes, no) }\end{array}$ & $\begin{array}{l}\text { health-related questions (none, } \\
1 \text { to } 2,3 \text { to } 5 \text { ) }\end{array}$ & & & \\
\hline 4 & $\begin{array}{l}\text { The frequency with which } \\
\text { librarians help patrons with } \\
\text { health information needs (never, } \\
\text { a few times a year, a few times a } \\
\text { month, a few times a week, daily) }\end{array}$ & $\begin{array}{l}\text { Library setting (urban, } \\
\text { suburban, rural, mixed) }\end{array}$ & 23.489 & 12 & .024 \\
\hline 5 & $\begin{array}{l}\text { The frequency with which } \\
\text { librarians help patrons with } \\
\text { health information needs (never, } \\
\text { a few times a year, a few times a } \\
\text { month, a few times a week, daily) }\end{array}$ & $\begin{array}{l}\text { The content variety of health- } \\
\text { related questions librarians } \\
\text { receive, represented by the } \\
\text { number of content topics ( } 1 \text { to } \\
3,4 \text { to } 6 \text {, more than } 6 \text { ) }\end{array}$ & 87.669 & 6 & .000 \\
\hline 6 & $\begin{array}{l}\text { The frequency with which } \\
\text { librarians help patrons with } \\
\text { health information needs (never, } \\
\text { a few times a year, a few times a } \\
\text { month, a few times a week, daily) }\end{array}$ & $\begin{array}{l}\text { The number of desired topics in } \\
\text { a consumer health information } \\
\text { training curriculum ( } 1 \text { to } 3,4 \text { to } \\
6,7 \text { to } 10 \text { ) }\end{array}$ & 21.426 & 6 & .002 \\
\hline
\end{tabular}

Table 4. Chi-square test results for rejected null-hypotheses

The cross-tabulation analysis indicated that:

- Librarians with a higher frequency of helping patrons with health information needs face a larger number of challenges.

- Librarians without any training on serving patrons with health information needs face a larger number of challenges than those with.

- Librarians working in urban libraries have a higher frequency of helping patrons with health information needs than those working in suburban or rural libraries.

- Librarians with a higher frequency of helping patrons with health information needs encounter a larger content variety of health-related questions.

- Librarians with a higher frequency of helping patrons with health information needs expect to see more topics covered in a consumer health information service training curriculum.

\section{Discussion}

6.1. Understanding patrons' health information needs

All three research questions were fully answered by this study. The answer to the first research question indicates that the types of consumer health information needs encountered by public librarians are primarily congruous with reports in the literature. Baker et al. (1998) found that the top three ranked health-related questions were about specific diseases, drugs, and disease 
prevention or health promotion, and in Wessel et al.'s (2003) study, the top three were about specific diseases, drugs or medications, and alternative therapies and modalities. This study discovered that the top three categories to be questions seeking factual information about the human body, a medical/health condition, a disease, or a medical concept, questions about fitness/diet/nutrition, and questions about the treatment options/healing process of a medical/health condition or a disease, including complementary and alternative therapies. A comparative look at the three studies suggests that over the years, information about specific diseases, drugs, treatment and health promotion or healthy living is consistently popular among public library patrons' demand.

\subsection{Grasping the challenges faced by public librarians}

The second research question sought to determine the challenges faced by public librarians when assisting patrons with health information needs, and its answer, again, echoed findings from previous studies (Marshall et al., 1991; Sprang \& Baker, 2000, Wessel et al., 2003; Linna et al., 2004; Kouame et al., 2005). However, the challenges identified in this study were rankordered, providing a prioritized view on which challenges are more commonly recognized and which ones are less. The number one challenge, "Difficulty in interpreting patrons' questions", was identified by two-thirds of the respondents, twice the number of respondents that identified the second-ranked challenge. The causes for the difficulty comprised the various problems in patrons' communicating their information needs to librarians, such as patrons not being able to articulate their questions, or provide correct spelling or pronunciation of the medical terms in their questions. The prevalent acknowledgment of this challenge has implications not only for librarian training and education, but also for retrieval system design for online medical/health information resources. When patrons conduct information searches on their own, the same issues preventing librarians from successfully interpreting their information needs will also hinder their information quests in online resources. Therefore, it is important for system design professionals to become aware of the common problems people have when formulating and presenting their medical/health information needs, and design information retrieval systems that could overcome these hurdles and achieve optimal outcomes.

Another challenge worth noting was that many library patrons prefer print resources, and it is difficult to meet their needs as the library lacks up-to-date print collections on medical/health topics. Their print-oriented mindset also makes it difficult for librarians to encourage patrons to migrate from books to online resources. This is likely to explain the reference desk being the predominant venue where librarians encounter health-related questions. Meanwhile, it highlights the importance of educating library patrons about the advantages of online resources (e.g. better currency) in meeting their health information needs. Apparently, the meaningful solution to this challenge is not costly investment in print collections. Instead, active patron outreach needs to be conducted to increase their awareness of the value of online resources and help them understand that their questions can be more effectively and efficiently answered using online resources. Patrons' mindset shift is critical in successfully providing health information service to them. 
Librarians experiencing a higher number of challenges tend to be those without any consumer health information service training and those who encounter health-related questions more frequently. This conclusion confirms the necessity of providing training for public librarians, especially those working in urban settings, who, as discovered in the study, usually witness a higher frequency of health-related questions than those working in suburban and rural areas. While training is indispensable for librarians to overcome the challenges in offering health information service, more than half of the librarians in the study had not received any, suggesting that more efforts are needed to enhance awareness and communications about available training opportunities, and create effective and efficient training programs that meet the needs of public librarians.

\subsection{Meeting the training needs of public librarians}

The third research question aimed at discovering the desired content and delivery options of consumer health information service training, and the findings indicated the topics librarians wished to see covered in training were aligned with the challenges they faced. For example, the top two training topics, knowledge/navigation of up-to-date health information resources, and health reference interview, corresponded with the top two challenges, difficulty in interpreting patrons' questions and lack of knowledge about available medical/health information sources. On the topic of medical/health information sources, one issue concerning librarians was that much of the medical/health information is written at a professional level and too technical for patrons' reading comprehension. Consequently, it can be difficult for librarians to gauge whether the information is appropriate for a patron's reading level. This finding was consistent with what Chobot (2002) detected in her literature review of how public libraries disseminate health information. Thus, in training design, it is critical to address this issue and prepare librarians with knowledge of medical terminology as well as layman-oriented sources. Nonetheless, the ultimate solution needs to come from the medical/health information industry - they need to become aware of the discrepancy between the technical nature of much of the medical/health information and people's limited capability in interpreting it. This discrepancy has impeded people's successful use of medical/health information, and to mitigate it, it is necessary to create information sources that are geared toward consumers instead of professionals, and present medical/health information in ways that are easily comprehensible and digestible.

Baker and Manbeck (2002), in their book about consumer health information for public librarians, identified the educational requirements for public librarians to be communication and reference skills, debriefing, medical terminology, knowledge of sources, ethical issues, and anonymity and confidentiality, similar to Linnan et al.'s (2004) findings. A decade later, these requirements are still among the top demanded training topics, with only one exception -"debriefing". Baker and Manbeck suggested that libraries provide training on handling stress and create an environment where librarians can talk about their experiences and feelings as venting helps them acknowledge the emotional toll of answering health-related questions. However, in this study, librarians did not consider "debriefing" or stress management as a training topic specifically related to consumer health information service. One possible explanation might be that over the past decade the stress level in the workplace has increased 
in general, and stress management skills have become an innate element in librarians' qualifications and they no longer associate the skill set with providing consumer health information service.

Building upon Baker and Manbeck (2002) and Linnan et al. (2004), this study determined a number of new training topics, among which a highly desired one was serving health information needs of special populations, particularly the vulnerable and disadvantaged. As discussed previously, seniors, immigrants, low-income and low-literacy individuals tend to have a low level of health literacy and they are usually a major audience of public libraries' consumer health information service. Health literacy is a complex topic where issues of culture, language, and learning are interrelated (Whelan, 2009), and for special populations, librarians' understanding of these issues and their interrelations is key to successfully communicating with them and helping them fulfill their information needs. Meanwhile, the number of topics librarians wished to be covered in training was positively related to the frequency with which they answer health-related questions. The frequency tends to be higher in urban libraries, possibly due to the diversity of urban populations, including special populations. Thus, training for urban librarians needs to have more content varieties to meet their needs.

Another popular training topic that emerged from this study was marketing library programs and services about consumer health information. In a study of (Borman \& McKenzie, 2005) barriers in the reference transaction between librarians and patrons, one barrier specific to consumer health information service was the lack of awareness of the services public libraries provide. Despite the insatiable demand for health information, some potential patrons, characterized as "still on the sidelines" by Tu and Hargraves (2003), have not yet taken advantage of public library services. Active service promotion and community outreach is essential in raising awareness of public libraries' offering of health information assistance and encouraging more people to seek help from public librarians.

As for the way training should be delivered, the most popular option, among all that were provided in the survey, was self-paced online tutorials, which was selected by more than $51 \%$ of the librarians, while the second most popular delivery formats, face-to-face in-house training and online real-time (synchronous) training via Webinars, only received a little over $18 \%$ of the votes. The dominant preference toward self-paced online tutorials may have two contributing factors: 1) since Internet and computer access has become ubiquitous, online learning is playing a more important role in librarians' professional development; 2) public librarians usually have a busy work schedule, and flexibility of the training format affords them better control of the learning process. However, as shown in the literature review, there has been no report of consumer health information service training in the form of self-paced online tutorials. Clearly, this is a gap that should be bridged soon in order to most effectively and efficiently provide public librarians with the training they need.

To design self-paced online training tutorials, public libraries may consider partnering with medical/health libraries. One key finding from Chobot's (2002) analysis of how public libraries provide consumer health information was "regional networks, consortia and other partnerships 
play an important role in meeting the health information needs of consumers" (p. 12), indicating that public libraries can draw upon the well-established resources and expertise of professionals from medical/health libraries. NLM conducted a study to learn about the role of public libraries in providing health information to the public (Wood, Lyon, Schell, Kitendaugh, Cid \& Siegel, 2000), and the purpose of the study was to generate information that would assist NLM and the National Network of Libraries of Medicine (NN/LM) in understanding how best to work with public libraries in the future. This suggests that the community of medical/health sciences libraries is interested in partnering with public libraries in the cause of improving the nation's health literacy. Public librarians, as shown in this study, also expressed desire to learn more about partnering with health organizations in fulfilling patrons' health information needs. Given the bilateral interest in forging partnerships, public libraries may approach medical/health sciences libraries for assistance in developing self-paced online training tutorials for public librarians. In fact, as reported by librarians in this study, organizations like NNLM and $\mathrm{NIH}$ and medical/health libraries had already been providing localized training to public librarians via Webinars and face-to-face sessions. The format of online tutorials can be a further step along this line of efforts, aiming to reach a wider audience with a greater impact. The training topics identified in this study, as well as other findings, may serve as a guide for libraries to determine the priorities and specifics of the tutorial content, and eventually create training tutorials that meet the needs of public librarians and can successfully prepare them for consumer health information services.

\section{Conclusion}

This study was the first nationwide effort to understand how to prepare public librarians for consumer health information service. It constitutes the basis to establish training requirements and develop training programs to meet the needs of public librarians. Their mastery of the necessary skills, knowledge and competencies via training is crucial to the effective and efficient delivery of consumer health information service in public libraries.

Practitioners and educators gain from the study enhanced knowledge of the various types of health information needs encountered by public librarians, a clear view of the challenges they face when providing consumer health information service, and most importantly, a thorough and solid understanding of their training needs. Training is indispensable to public librarians' success in helping patrons fulfill their health information needs, and this study helps address two key issues in providing training to librarians - what topics to cover and how to deliver it. Understanding librarians' desired training format and their desired training topics, practitioners and educators will be able to make informed decisions in designing training and education programs for them.

This study lays foundation to the development of specific content of training and education for public librarians. The study findings may guide researchers and educators in their investigation of what content to cover, what to leave out, what to emphasize, and what to minimize for each training topic desired by librarians, as well as how to convey the content via librarians' favorite training format, self-paced online tutorial. Training programs created on the basis of this study will be able to reflect the genuine needs of public librarians and successfully equip librarians with the capability to overcome the challenges encountered when assisting patrons with their 
health information needs, and help librarians become more confident and competent in the area of consumer health information. Ultimately, improved librarian preparedness will be beneficial to patrons and lead to optimal patron experience when they seek health information assistance from public librarians.

\section{References}

American Hospital Association (AHA). (2007). Baby boomers to challenge and change tomorrow's health care system. Retrieved from http://www.aha.org/presscenter/pressrel/2007/070508-pr-boomers.shtml

Baker, L. M., \& Manbeck, V. (2002). Consumer health information for public librarians. Lanham, MD: Scarecrow Press.

Baker, L. M., Sprang, L., \& Gogolowski, C. (1998). The provision of consumer health information by Michigan public libraries. Public Libraries, 37(4), 250-255.

Bass, L. (2005). Health literacy: Implications for teaching the adult patient. Journal of Infusion Nursing, 28(1), 15-22.

Berkman, N. D., DeWalt, D. A., Pignone, M. P., Sheridan, S. L., Lohr, K. N., Lux, L, Sutton, S. F., Swinson, T., \& Bonito, A. J. (2004). Literacy and health outcomes: Summary. Evidence Report/Technology Assessment, No. 87. Retrieved from http://www.anrq.gov/clinic/epcsums/litsum.pdf.

Borman, C. B., \& McKenzie, P. (2005). Trying to help without getting in their faces: Public library staff descriptions of providing consumer health information. Reference \& User Services Quarterly, 45(2), 122-46.

Carmona, R. H. (2006). Health literacy: A national priority. Journal of General Internal Medicine, 21(8), 803.

Chobot, M. C. (2002). The challenge of providing consumer health information services in public libraries. Washington DC: American Association for the Advancement of Science.

Council on Scientific Affairs of the American Medical Association (CSAAMA). (1999). Health literacy: report for the AMA council on scientific affairs. Journal American Medical Association, 281(6), 552-57.

Derring, M. J., \& Harris, J. (1996). Consumer health information demand and delivery: Implications for libraries. Bulletin of the Medical Library Association, 81(2), 209-216.

Erlen, J. A. (2004). Functional health literacy: Ethical concerns. Journal of Orthopaedic Nursing, 23(2), 150-3.

Eysenbach, G., \& Köhler, C. (2002). How do consumers search for and appraise health information on the World Wide Web: Qualitative study using focus groups, usability tests and in-depth interviews. British Medical Journal, 324(7337): 573-77. 
Eysenbach, G., Powell, J., Kuss, O., \& Sa, E.R. (2002). Empirical studies assessing the quality of health information for consumers on the World Wide Web. Journal of the American Medical Association, 287(20), 2691-700.

Fox, S. (2006). Online health search 2006. Retrieved from http://www.pewinternet.org/Reports/2006/Online-Health-Search-2006.aspx.

Harris, R., \& Wathen, N. (2007). If my mother was alive, I'd probably have called her. Reference \& User Services Quarterly, 47(1), 67-79.

Harris, R., Wathen, N., \& Chan, D. (2005). Public library responses to a consumer health inquiry in a public health crisis. Reference \& User Services Quarterly, 45(2), 147-54.

Institute of Medicine (IOM). (2003). Executive Summary. Priority areas for national action: Transforming health care quality. Washington, DC: National Academies Press, 2003. Retrieved from http://www.nap.edu/execsumm/ 0309085438.html\#sum

Kouame, G., Harris, M., \& Murray, S. (2005). Consumer health information from both sides of the reference desk. Library Trends, 53(3), 466-79.

Kripalani, S., \& Weiss, B. D. (2006). Teaching about health literacy and clear communication. Journal of General Internal Medicine, 21(8), 888-90.

Linnan, L., Wildemuth, B. M., Gollop, C., Hull, P., Silbajoris, C., \& Monnig, R. (2004). Public librarians as a resource for promoting health: Results from the Health for Everyone in Libraries Project (HELP) Librarian Survey. Health Promotion Practice, 5(2), 182-90.

Lyon, B. J. (2001). The National Library of Medicine and health information for the public. Public Libraries, 40(2), 107-109.

Malachowski, M. (2011). Patient activation: Public libraries and health literacy. Computers in Libraries, December 2011, 5-9.

Marcus, E. N. (2006). The silent epidemic-the health effects of illiteracy. The New England Journal of Medicine, 355(4), 339-41.

Marshall, J. G., Sewards, C., \& Dilworth, E. L. (1991). Health information series in Ontario public libraries. Canadian Library Journal, 98, 37-44.

McCray, A. T. (2005). Promoting health literacy. Journal of the American Medical Informatics Association, 12(2), 152-63.

National Library of Medicine (NLM). (2004). Strategic plan for addressing health disparities 2004-2008. Bethesda, MD: National Library of Medicine. Retrieved from http://www.nlm.nih.gov/pubs/plan/nlm_health_disp_2004_2008.html.

Nielsen-Bohlman, L., Panzer, A. M., \& Kindig, D. A. (2004). Health literacy: A prescription to end confusion. Washington, DC: The National Academies Press.

Norman, C. D., \& Skinner, H. A. (2006). eHealth literacy: Essential skills for consumer health in a networked world. Journal of Medical Internet Research, 8(2), 9. 
Orban, E. (2005). Health literacy: Challenges and implications for consumer health librarians. Indiana Libraries, 24(3), 2-6.

Nutly, D. D. (2008). The adequacy of response rates to online and paper surveys: what can be done? Assessment \& Evaluation in Higher Education, 33(3), 301-314.

Parker R. (2000). Health literacy: A challenge for American patients and their health care providers. Health Promotion International, 15(4), 277-83.

Parker, R., \& Kreps, G. L. (2005). Library outreach: Overcoming health literacy challenges. Journal of the Medical Library Association, 93(4), S81-85.

Parker, R. M., Ratzan, S. C., \& Lurie, N. (2003). Health literacy: A policy challenge for advancing high-quality health care. Health Affairs, 22(4),147-53.

Rudd, R. E., Moeykens, B. A., \& Colton, T. C. (1999). Health and literacy: A review of medical and public health literature. In Comings J, Garners B, Smith C, eds. Annual review of adult learning and literacy. New York, NY: Jossey-Bass.

Siegel, E. R. (2007). MedlinePlus and the challenge of low health literacy: Findings from the Colonias project. Journal of the Medical Library Association, 95(1), 31-9.

Sprang, L., \& Baker, L. M. (2000). Healthcare information delivery in public libraries: Implications for academic reference librarians. Reference Services Review, 28(1), 81-94.

Tu, H. T., \& Hargraves, J. L. (2003). Seeking health care information: Most consumers still on the sidelines. Issue Briefs, Center for the Study of Health Systems Change, 61, 1-4.

Turner-McGrievy, G. M., \& Campbell M. K. (2009). Nutrition information to the desktop: A pilot online nutrition course on saturated fat for public librarians increases knowledge, expectancies, and self-efficacy. Journal of Nutrition Education and Behavior 41(3), 188-193.

US Department of Health and Human Services (HHS). (2010). National action plan to improve health literacy. Retrieved from http://www.health.gov/communication/hlactionplan/pdf/Health Lit Action Plan Summar y.pdf

Westermann-Cicio, M. L. (2003). Bringing quality electronic information to the health care consumer: Library collaborations that work. Journal of Consumer Health on the Internet, 7(1), 2.

Wessel, C. B., Wozar, J. A., \& Epstein, B. A. (2003). The role of the academic medical center library in training public librarians. Journal of Medical Library Association, 91(3), 352-360.

Whelan, J. S. (2009). Making health literacy real: Adult literacy and medical students teach each other. Journal of the Medical Library Association, 97(3), 221-4.

Wood, F. B., Lyon, B., Schell, M. B., Kitendaugh, P., Cid, V. H., \& Siegel, E. R. (2000). Public library consumer health information pilot project: Results of a National Library of Medicine evaluation. Bulletin of the Medical Library Association, 88(4), 314-322.

Zarcadoolas, C., Pleasant, A., \& Greer DS. (2005). Understanding health literacy: An expanded model. Health Promotion International, 20(2), 195-03. 
Zionts, N. D., Apter, J., Kuchta, J., \& Greenhouse, P. K. (2010). Promoting consumer health literacy: Creation of a health information librarian fellowship. Reference \& User Services Quarterly, 49(4), 350-59. 